Marko Erzar, Klara Horvat, Zarja Klun, Maja Maraそ̌, Kristjan Mibelic in Drago Švajger

\title{
Aktivno ustvarjanje glasbe kot način za zmanjševanje socialne anksioznosti mladostnikov - pilotska raziskava
}

\section{Active Music Making as a Route to Diminished Social Anxiety among Adolescents - A Pilot Study}

Povžetek: V članku, ki temelji na pilotski raziskavi Aktivno ustvarjanje glasbe kot način za zmanjševanje socialne anksioznosti mladostnikov, smo raziskovali, kakšen vpliv ima glasba na možgane mladostnikov in kako lahko to znanje uporabimo za čustveno opismenjevanje mladostnikov, ki so bili vključeni v raziskavo. $\checkmark$ začetnem delu članka smo se osredotočili na mladostnika in razvoj mladostniških možganov ter na pomen glasbe $v$ tem ključnem obdobju razvoja. Nato smo se osredotočili na glasbo in pozitivne učinke, ki jih ima na človeške možgane, ter na možnost povezave med glasbo in učenjem čustvene regulacije. Glasba je že od nekdaj tisto, kar ljudi povezuje, saj je že sam glas prvi stik z muzikaličnostjo, ki nas obdaja od spočetja naprej. Glas v sebi nosi različne čustvene nianse, sporoča, v kakšnem fizičnem in čustvenem stanju je naš sogovornik, ter predstavlja most med posameznikom in soljudmi. Skupina mladostnikov, ki je sodelovala v naši raziskavi, se je učila uporabljati ravno glas kot orodje za čustveno oporo. Skozi vaje kultiviranja glasu kot notranje moči človeka so se hkrati učili tudi čustvene regulacije, krepili občutek za jaz, spoznavali sami sebe, presegali pričakovanja, ki so jih imeli o sebi, obenem pa se zabavali in gradili svoj izraz v skupini. Raziskovali smo še, na kakšen način lahko uporabljamo pevske in instrumentalne tehnike v terapevtske namene - čeprav naša raziskava ni bila namenjena raziskovanju učinkov terapije z glasbo. Vseeno pa smo ob oblikovanju pevskih in igralnih delavnic za mladostnike ugotovili, da je bil naš cilj dosežen - glas in učenje ob glasbi smo uporabili kot terapevtsko intervencijo pri delu z mladimi, kjer se je pokazalo, da sta se stanje socialne anksioznosti in zadržanosti zmanjšala.

Ključne besede: glasba, mladostniki, socialna anksioznost, izražanje, razvoj

Abstract: In this article, based on the pilot study Active music creation as a way of reducing the social anxiety of adolescents, we have explored the importan- 
ce of music on the minds of adolescents and how this knowledge can be used for the emotional literacy of adolescents who participated in the study. In the first part of the article, we focused on adolescents and the development of an adolescent brain, and what music means in this crucial period of development. Furthermore, we focused on the music and its positive effects on the human brain, and how we can connect music with the teaching of emotional regulation. Music has always been what connects people since the voice itself is the first contact with the musicality that surrounds us from the conception onwards. The voice itself carries all emotional nuances, it communicates in what physical and emotional condition a speaker is and offers a bridge between "us " and "others". A group of adolescents who participated in our study learned to use their voices as a tool that offers emotional support. Through the exercises of cultivating this inner strength (their voice), they also learned emotional regulation, strengthening the sense of "self «; they were learning who they were, exceeded the expectations they had about themselves, and at the same time enjoyed themselves and built their own expression in the group. We also explored how we can use singing and instrumental techniques for therapeutic purposes, although our research was not intended to examine the effects of music therapy. Nevertheless, when creating singing and acting workshops for adolescents, we realized that our goal was achieved. Using the voice and learning with music were used as a therapeutic intervention in working with young people and the levels of social anxiety and restraint were shown to have decreased.

Key words: music, adolescents, social anxiety, expression, development

\section{Uvod}

Vedno več raziskav potrjuje izjemno široke pozitivne učinke glasbenega izobraževanja in udejstvovanja na razvoj otrok in mladostnikov. Dokazani so tudi učinki glasbenih delavnic na preprečevanje postravmatske stresne motnje (PTSD) in kot pomoč otrokom in mladostnikom, ki so žrtev različnih travmatičnih dogodkov, zanemarjanj in zlorab. Več študij obravnava terapijo z glasbo kot sredstvo za raziskovanje samega sebe in svojega čustvenega doživljanja (Sausser 2006, 138). Temeljni učinek, ki ga ima glasba, predvsem kadar gre za aktivno izvajanje, ki poteka po jasno izdelanem strukturiranem zaporedju (od dela na ritmu do oblikovanja melodije in petja ter nazadnje skupnega muziciranja in priprave kratkega recitala), je prav regulacija težkih čustvenih vsebin, ki se kažejo kot tesnoba, čustveni nemir, težave s pozornostjo in obvladovanjem impulzov ter nesposobnost čustvenega izražanja oziroma govorjenja o čustvih ter razumevanja svojega čustvenega stanja. Čustvena pismenost, ki je eden temeljnih pogojev za razvoj sposobnosti čustvene regulacije, socialno vključevanje in vzpostavljanje prijateljskih medosebnih odnosov, se namreč razvija po istih poteh kot glasba. Muzikaličnost je najpomembnej- 
ši znak čustveno varnih in trdnih odnosov. Z razvojem glasu (petje) in integracije uho - oko - roka (igranje inštrumenta, sploh klavirja, kjer se uporablja dvoročno igranje) razvijamo nevronske poti, ki odpirajo pot do lažjega socialnega povezovanja.

\section{Teoretični del}

\subsection{Mladostništvo}

Mladostništvo ali puberteta je obdobje, v katerem prihaja do pomembnih količinskih in kakovostnih sprememb v spoznavnih sposobnostih, logičnem mišljenju, procesiranju informacij in razumevanju predmetnega ter socialnega okolja (Zupančič in Svetina: v Marjanovič Umek 2009, 525) in katerega začetek sovpada z ustvarjanjem dokončnih temeljev v možganih posameznika, ki bodo predstavljali osnovo njegovim odraslim odnosom (Gostečnik 2016, 83). Fizična in kognitivna rast ter razvoj možganskih struktur mladostniku omogočajo progresivne spremembe na mnogih področjih delovanja (Zupančič in Svetlina 2011, 69), zato bolj kot kadarkoli prej razume informacije iz okolja in jih integrira v svoj repertoar védenja in delovanja (Feinstain 2013; Steinberg 2014: v Gostečnik 2016, 259). Preoblikovan miselni sistem mladostnika, ki preide od konkretnega k abstraktnemu, pa odpira povečano sposobnost razumevanja in procesiranja emocij (Kompan Erzar 2003, 163). Ena izmed pomembnejših razvojnih nalog mladostnika je reorganizacija njegovega odnosa s starši (Allison in Sabatelli 1988; Grotevant in Cooper 1986: v Puklek Levpušček 2003, 72). Družinski odnosi so vir topline, sreče, zadovoljstva, lahko pa tudi stiske in travme (Simonič 2015, 67). Posamezni družinski člani in družinski sistem so v nenehnem procesu dinamičnega prilagajanja, kar pride v obdobju mladostništva do izraza še toliko bolj (Pate 2016, 435). Posledično je to tudi obdobje, v katerem stopijo pri mladostniku v ospredje skrbi v zvezi z negativnim socialnim vrednotenjem. Socialni kontekst mladostnikovega delovanja se vse bolj razširja, vrstniške interakcije in odnosi postajajo vse pomembnejši del njegovega življenja in pomembna mladostnikova referenčna skupina ter prostor preizkušanja identitete (Puklek Levpušček 2006; Gomezel in Kobolt 2012; Zupančič 2011, 69). Vrstniki so model za posnemanje obnašanja, vir tolažbe, pa tudi vir draženja (Kuhar 2002, 271). Mladostniki doživljajo veliko radosti, veselja, pozitivnih pričakovanj, vznemirjenja, izkušajo pa tudi znatno mero negotovosti in dvoma vase, žalosti, anksioznosti, osamljenosti in zaskrbljenosti glede prihodnosti (Conger 1999: v Zupančič in Marjanovič Umek 2009, 521).V tem obdobju različnih pritiskov je zato vedno bolj pomemben prosti čas, ki ga opredeljujejo raznovrstne dejavnosti (Denac 2013, 114). Izredno pomembno za mladostnika je, da v tem obdobju veliko bere, piše in se ukvarja s kulturo, saj imajo te dejavnosti zelo pomemben vpliv na njegove razvijajoče se možgane. Znanstveniki ob tem ugotavljajo, da ima glasba še posebej velik vpliv na emocionalno počutje, različne mladostnikove zmožnosti in sposobnosti (Feinstein 2013; Steinberg 2014: v Gostečnik 2016, 173). 


\subsection{Glasba in njene oblike}

\subsubsection{Glasba in glas kot ključni dejavnik razvoja}

Človeški glas je biološko komunikacijsko orodje, s katerim se človek začne spoznavati že v prenatalnem obdobju. Vsak dojenček posluša svojo mater ter zvoke, besede in pesmi, ki jih sliši iz okolja. Tako vsak otrok razvije svoj edinstven, poseben in nenadomestljiv glas, ki je tesno povezan z njegovimi čustvi in umom. $Z$ glasom razkrivamo del sebe, svojo osebnost, globino čutenj in misli. Človeški glas se postavlja visoko nad druge instrumente, saj govorjenje v sebi lahko nosi intimen, direkten in nadčuten naboj.Otrok se skozi razvoj sooča z različnimi spremembami, tudi na področju razvoja glasu, dečki pa spremembe doživijo še bolj intenzivno zaradi mutacije glasu. Glas se razvija pri vsakem posamezniku z različno hitrostjo, gre pa tudi čez različna obdobja, zato lahko govorimo o otroškem glasu, odraslem glasu in glasu v starosti (Malloch in Trevarthen 2010). Glas močno odraža razvoj in je občutljiv na najrazličnejše dejavnike, predvsem uporabo in pravilno oblikovanje pevskega aparata. Glasba, predvsem petje, je zato lahko terapevtska dejavnost, saj z njo dosežemo strategije oblikovanja čustvenega odziva ali spremembo čustvenega odziva (MrRae et al. 2010, 456).

"Glasba se dotakne naših občutij globlje kot beseda in v nas prebudi celovit odziv. Morda to ne velja prav za vso glasbo, vsekakor pa je to ena stran kontinuuma jezik - glasba. V vsakem primeru pa glas in čustva igrajo osrednjo vlogo pri soevoluciji glasbe in jezika ter predstavljajo najmočnejša elementa vsakodnevne govorne komunikacije in ustvarjanja glasbe." (Airbib 2013, 413)

\subsubsection{Oblike glasbenih aktivnosti in izražanja skozi glasbo}

Pri terapiji z glasbo se uporabljajo različne glasbene dejavnosti, ki posamezniku pomagajo pri odkrivanju notranjih svetov. Med te aktivnosti spadajo izvajanje (petje, igranje z glasbili oziroma inštrumentalno izvajanje, gibanje ob glasbi), poslušanje in ustvarjanje (ples, slikanje ob glasbi) (Pepelnak Arnerič 1997; Žvar et al. 2008 , 345). Petje predstavlja aktivno obliko učenja, medtem ko je gibanje ob glasbi ena najstarejših izraznih oblik čustev (Žvar et al. 2008, 115). Glasbena aktivnost enakovredno zaposluje možganske funkcije obeh hemisfer hkrati, in sicer bolj kot katera koli druga dejavnost (Lešnik 2015, 73), prav tako pa glasbeno udejstvovanje ob različnih nastopih vsekakor vpliva na otrokovo samopodobo, navadno pozitivno (Goetze v Lešnik 1985, 232). Petje je poleg poslušanja glasbe ena izmed najbolj razširjenih aktivnosti, ki jih izvajajo mladi. Med oblike petja spadajo solopetje, petje $v$ pevskem zboru in petje $v$ skupini. Solopetje navadno spremlja glasbena spremljava, kar imenujemo komorna glasba. To je izraz za skladbe, ki so komponirane za manjše zasedbe (1-10 izvajalcev), vsak del partiture pa izvaja po en glasbenik. Komorno glasbo ločimo glede na število izvajalcev (solo, duo, trio, kvartet, kvintet, sekstet, septet, oktet, nonet in decet), prav tako pa se loči glede na število glasbil v postavitvi. Če je izvajalcev glasbe več kot 11 , se zasedba imenuje 
komorni orkester, kadar pa je izvajalcev od 21 do 100 ali več, zasedbo imenujemo simfonični orkester. Pevski zbor je vokalna glasbena skupina, kjer posamezni del skladbe izvaja več pevcev hkrati, glasbena spremljava pa ni nujna. Poleg petja in poslušanja glasbe poznamo tudi obliko, kjer se petju in igranju na inštrumente pridruži telesni izraz, to je muzikal. Gre za glasbeno-scensko delo, ki se je razvilo iz operete in pri katerem gre za kombinacijo petja, pesmi, plesa, igranja in govorjenja.

\subsection{Glasba in njena uporaba $v$ terapevtske namene}

Stein $(1999,89)$ razume glasbo kot primarno procesno izkušnjo, ki nasprotuje slišanemu, saj prebuja naša občutja. Mnogi avtorji opredeljeujejo čustva ne samo kot pozitivna in negativna, temveč tudi kot tako imenovana trda ali dominantna in mehka ali submisivna (Čotar Konrad 2016, 321-322; Sanford 2007, 65-70 v Konrad in Perko 2018, 252), ki so lahko ali pozitivna ali negativna. Glasba deluje kot medij, ki ima neposreden dostop do človekovega čustvenega in podzavestnega sveta in je prirojena vsakemu človeku. McDermott, Houser $(2006,62)$ in Disanayake $(2009,45)$ trdijo, da glasba krepi medsebojno povezovanje in komunikacijo ter ustvarja stik, zato je lahko terapevtska, saj z njo usvajamo strategije oblikovanja čustvenega odziva ali dosežemo spremembo čustvenega odziva (McRae et al. $2010,89)$. Uglašena umetniška kreacija omogoči posamezniku, da se vanjo čustveno vključi, pritegne njegovo notranjo pozornost (telesni, čustveni odziv), jo oblikuje in skozi oblikovanje pomena tudi regulira ter zaključi tako, da skupaj z njim ustvari nov čustveni prostor. Ta nov čustven prostor pa je tisti, ki poganja razvoj (Kompan Erzar 2015, 78).

\subsubsection{Glasba kot terapevtsko sredstvo}

Glasba kot terapevtska metoda se je začela sistematično uporabljati v 20. stoletju. Glasbena terapija se je z leti vse bolj razvijala in postajala terapevtsko sredstvo za pomoč pri različnih stiskah in lajšanju najrazličnejših simptomov (Landis-Schacket al. 2017, 116). Mrazova in Celec $(2010,110)$ pojasnjujeta, da lahko glasbeno-terapevtske oblike delimo na aktivne in pasivne. $Z$ vidika nevroznanosti se pasivne in aktivne glasbene dejavnosti razlikujejo po delih možganov, ki jih aktivirajo. Terapevtske tehnike, ki spadajo med aktivne, vključujejo igranje inštrumentov, petje, glasbeno improvizacijo, pisanje besedil in pesmi, med pasivnimi pa navajata oblike, kot so poslušanje glasbe in različnih drugih zvokov.

\subsubsection{Glasba in mladostnik}

Glasbena terapija ima med vsemi oblikami terapije pri terapevtski obravnavi mladostnikov prav posebno vlogo (Tervo 2006, 182). Tervo poudarja, da sama glasba pri glasbeno-terapevtski obravnavi mladostnikov nima najpomembnejšega učinka, saj je potrebna tudi psihoterapevtska intervencija. Študija Effects of Active Versus Passive Group Music Therapy on Preadolescents with Emotional, Learning, and Behavioral Disorders avtorjev Montella in Coonsa $(1999,156)$ je raziskovala učinke aktivne in pasivne glasbene terapije. Raziskovalci so ugotovili, da se je nepri- 
merno vedenje udeležencev po prejemu obeh intervencij glasbene terapije znatno popravilo in da lahko prav skupinska oblika glasbene terapije olajša proces samoizražanja v situacijah čustvenega vznemirjenja in zagotovi kanal za pretvarjanje frustracije, jeze in agresije v izkušnje ustvarjalnosti in samoizražanja.

Še ena raziskava, ki jo je vredno omeniti, je Paulanderjeva The meaning of going in music therapy. A phenomenological study on the participants' experiences (2011, 132). Ta raziskava je pokazala, da so udeleženci glasbene terapije, ki je vključevala pogovor, mnogo bolje razumeli občutja in globlje občutili glasbeno izkušnjo kot ob glasbenih terapijah, ki pogovora niso vključevale. Številne raziskave različnih avtorjev kažejo, da ima ukvarjanje z glasbo pri otrocih, še posebej glasbena terapija, ki vključuje elemente pevskih tehnik, statistično pomembne učinke na čustveno regulacijo, probleme z navezanostjo in na motnje v vedenju pri mladostnikih (Odell-Miller 2011, 237; Gold, Voracek, in Wigram 2004, 189; Kimbel in Protivnak 2010, 156). Študija The influence of group singing on trust and cooperation avtorjev Anshel in $\operatorname{Kipper}(1988,99)$ je raziskovala učinke, ki jih ima petje v skupini na zaupanje in sodelovanje. Rezultati so pokazali razvoj zaupanja in pripravljenosti sodelovati. Raziskava A Meta-Analysis on theEffects of Music as Reinforcement for Education/Therapy Objectives avtorja Standleyja $(1996,76)$ je ugotovila, da glasbena dejavnost utrjuje družbeno primerno vedenje, nanj vpliva blagodejno. Čeprav naš članek ne raziskuje glasbene terapije, pač pa strukturirano aktivno ukvarjanje z glasbo pri mladostnikih, rezultati omenjene študije nakazujejo, kako globoka izkušnja je lahko glasba. Pridobiti vpogled v to, kaj aktivno ukvarjanje z glasbo lahko ponudi mladostniku, je globlji cilj našega projekta.

\subsubsection{Oblikovanje glasbenih delavnic za mladostnike}

V sklopu projekta smo izvedli pilotsko študijo o povezanosti aktivnih glasbenih delavnic in čustvenega doživljanja mladostnikov. Delavnice, ki smo jih izvedli, so vključevale različne zvrsti glasbe, pevsko tehniko, petje v zboru in igranje klavirja. Izhajali smo iz predpostavke, da imajo razvoj glasu, trening glasu (sproščanje telesa, urejenost dihanja) in igranje glasbila močno povezavo z mladostnikovim čustvenim stanjem, predvsem z zmanjševanjem socialne tesnobe. Tesnoba je tista, ki se na glasu najbolj pozna, zato smo še posebej skrbno načrtovali uvodne dihalne vaje. Glasilke namreč ne morejo polno delovati, če je človek tesnoben in diha plitvo (Malloch in Trevarthen 2010, 343). Ob običajnem ustvarjanju glasu glasilke oddajajo razmeroma šibek zvok. Človeško dihanje glasilke razpre, ko pa začnemo peti, se glasilke napnejo in zožijo. Višje, ko pojemo, bolj se glasilke napenjajo in krčijo, zato je pravilna pevska tehnika na visokih delih zelo pomembna. Zaradi zračnega toka, ki priteka iz pljuč, glasilke nihajo. Z izdihom se zaprejo. »Zoženje prsnega koša in zaprtje glasilk iz pljuč ustvari povečan tlak, ki pa je neznaten v primerjavi z zunanjim tlakom. Periodično zaporedje odpiranja in zapiranja glasilk povzroči uhajanje večje ali manjše količine zraka iz grla v ustno votlino, in to zgoščevanje in razredčevanje zraka se odraža kot zvočno valovanje, in takrat nastane glas« (Žvar 2001, 89). Hkrati lahko s takim načinom dihanja ustvarimo tudi dru- 
gačno, manj tesnobno počutje. Podobno se zgodi pri igranju glasbila, kjer smo delo z mladostniki kombinirali na način, da so imeli individualen stik s pianistko. $\mathrm{Na}$ ta način smo jim omogočili navezovanje varnega stika, kjer so se v varnem okolju seznanili s skladbami in vajami. Imeli smo tudi skupinsko srečanje vseh dijakov, ki so bili vključeni v individualni pouk pri isti pianistki. Skupinska srečanja so mladostnikom omogočila medsebojno povezovanje, kar jih je še dodatno motiviralo pri individualnem delu.

\section{Empirični del}

\subsection{Kvantitativni del raziskovanja}

\subsubsection{Opis udeležencev raziskave}

Za naš projekt smo izbrali mladostnike, stare med 14 in 18 let, ki bivajo v dijaškem domu. Skupaj se je v našo raziskavo vključilo devet mladostnikov, od tega dva fanta in sedem deklet. Šest udeležencev raziskave se je udeležilo skupinskega petja, ostali trije pa učenja igranja klavirja. Do konca se je srečanj udeleževalo sedem mladostnikov. Na nastopu jih je nastopilo šest. Srečanja so potekala v Dijaškem domu Bežigrad, in sicer enkrat tedensko po eno uro in pol. Učenje klavirja je potekalo dvakrat tedensko, enkrat individualno in enkrat skupinsko.

\subsubsection{Raziskovalna vprašanja}

R1: Kaj aktivno vodena delavnica ukvarjanja z glasbo pomeni za mladostnikovo doživljanje sebe in stik z lastnimi čustvi?

R2: Ali ima na čustva usmerjeno aktivno ukvarjanje z glasbo in uglašeno skupno petje učinek na povezanost med mladostniki?

\subsubsection{Hipoteze}

H1: Strukturirano, aktivno ukvarjanje z glasbo omogoča lažje prepoznavanje in regulacijo čustev.

H2: Vključenost v aktivno vodene glasbene delavnice zmanjšuje stopnjo socialne anksiznosti pri mladostnikih.

H3: Aktivno glasbeno izražanje mladostnike spodbuja k medsebojnemu povezovanju.

\subsubsection{Opis instrumentov in potek raziskovanja}

$\checkmark$ raziskavi smo uporabili merski instrument "Lestvica socialne anksioznosti za mladostnike (LSAA)«, ki meri mladostnikovo doživljanje strahu, zaskrbljenosti in nesproščenosti v socialnih situacijah, v katerih mladostnik dejansko je ali zanje predpostavlja, da bo objekt negativnega vrednotenja drugih. Lestvica meri tudi 
zadržanost, pasivnost oz. vedenje umika v socialnih situacijah. Zajema tipične socialne situacije, $v$ katerih mladostnik doživlja socialno anksioznost: druženje $z$ vrstniki, vzpostavljanje in vzdrževanje stika z nepoznanimi vrstniki ali z vrstnikom nasprotnega spola, vrstniške zabave, izpostavljanje $v$ razredu in nastopanje.

Uporaba LSAA je primerna za mladostnike med 11. in 18. letom, s prilagoditvami nekaterih postavk pa lahko lestvico uporabljamo tudi pri študentih. Vsebuje dve podlestvici: "Zaskrbljenost in strah pred negativnim vrednotenjem (ZSNV)« ter "Tesnobnost in zadržanost v socialnem stiku (TZSS)«. Možen je tudi izračun skupnega rezultata na podlagi seštevka rezultatov na obeh podlestvicah. Mladostnik oceni pogostost doživljanja ali vedenja, ki ga opisuje vsaka postavka, na 5-stopenjski lestvici ( 1 - sploh ne, 2 - pretežno ne, 3 - včasih da, včasih ne, 4 pretežno da, 5 - vedno).

Podlestvica »Zaskrbljenost in strah pred negativnim socialnim vrednotenjem (ZSNV) « vsebuje 15 postavk. Postavke se nanašajo na spoznavno in čustveno komponento socialne anksioznosti. Mladostnik, ki ima na omenjeni podlestvici visok rezultat, je zaskrbljen in ga je strah zaradi dejanskega ali možnega negativnega vrednotenja vrstnikov (tako poznanih kot nepoznanih), možne izključenosti iz vrstniške družbe, grožnje negativne samopredstavitve v socialnem okolju ter možnih negativnih odzivov na njegov nastop $v$ javnosti.

Podlestvica »Tesnobnost in zadržanost v socialnem stiku (TZSS) « vsebuje 13 postavk. Te se nanašajo na vedenjsko in čustveno komponento socialne anksioznosti. Mladostnik, ki ima visok rezultat na tej podlestvici, je v stikih z vrstniki (s poznanimi vrstniki, z nepoznanimi vrstniki ali z vrstniki nasprotnega spola) zadržan, nesproščen, ne daje aktivnih pobud za vzpostavitev in vzdrževanje stikov, ne želi biti v središču pozornosti, v skupini vrstnikov pa se vede pasivno (npr. raje posluša kot govori).

LSAA je mogoče uporabljati individualno ali skupinsko. Z njeno pomočjo lahko:

- Identificiramo mladostnike, pri katerih je izražena socialna anksioznost, bodisi v spoznavni obliki kot zaskrbljenost zaradi negativnega socialnega vrednotenja bodisi v vedenjski obliki kot vedenjska zadržanost v socialnih situacijah;

- Ugotavljamo temeljna področja mladostnikovih težav v socialnih stikih, ki jih potem poglobljeno proučujemo s pomočjo kliničnega intervjuja;

- Ugotavljamo doživljanje in vedenje mladostnikov, ki imajo pomanjkljive socialne spretnosti ali teh ne znajo primerno uporabiti v določenih socialnih situacijah;

- Ugotavljamo vzroke mladostnikove manjše priljubljenosti med vrstniki, njegove socialne izoliranosti, nezmožnosti vzpostavljanja intimne zveze, slabšega učnega uspeha, slabšega odgovarjanja pri ustnem ali pisnem preverjanju znanja, pasivnosti pri pouku ipd.;

- Načrtujemo svetovalne oz. klinične intervence pri mladostnikih, ki poročajo o težavah v medosebnih (zlasti vrstniških) odnosih ali v situacijah, ko so javno izpostavljeni (npr. v razredu, pri nastopanju);

- Ugotavljamo uspešnost preventivnih ali terapevtskih programov, s katerimi 
izvajamo trening socialnih spretnosti pri mladostnikih (LSAA lahko uporabimo kot mero socialne anksioznosti pred izvajanjem programa in po njem);

- Raziskujemo socialno anksioznost mladostnikov v različnih obdobjih mladostništva ter njeno povezanost z drugimi psihološkimi spremenljivkami.

Podatke smo zbrali s pomočjo dveh vprašalnikov. Vprašalnik, namenjen staršem in pedagogom, je obsegal 58 vprašanj, medtem ko je vprašalnik za dijake obsegal 28 vprašanj. Pri obeh vprašalnikih smo izbrali zaprti tip vprašanj, saj smo na ta način najlažje pridobili informacije o dejanskem duševnem stanju otrok. V raziskavo smo poleg dijakov vključili še njihove vzgojitelje iz dijaškega doma, saj smo tako glede čustvenega razvoja otrok pridobili še dodatno (njihovo) mnenje. Raziskavo smo izvedli v enem od ljubljanskih dijaških domov. Anketiranih je bilo pet pedagogov. Vprašalnike za dijake smo razdelili na začetku izvajanja delavnic, da bi izmerili trenutno stanje socialne anksioznosti otrok. Vprašalnike smo dijakom zopet razdelili tik pred koncem izvajanja delavnic (na zadnji delavnici), da smo pridobili vpogled $v$ učinkovitost in uspešnost izvajanja delavnic na znižanje socialne anksioznosti. Vzgojiteljem smo vprašalnik lahko dali samo enkrat, da bi ugotovili, kako izbrane dijake doživljajo oni. Tako kot dijakom smo vzgojiteljem vprašalnik razdelili dvakrat, in sicer pred začetkom izvajanja delavnic in na koncu izvajanja.

\begin{tabular}{|c|c|c|c|c|c|c|c|}
\hline Dijak/dijakinja & Spol & Starost & ZSNV & TZSS & LSAA & Percentil & RSA \\
\hline Dijak št.1 & Ž & 15 let & 38 & 38 & 76 & 50 & Srednja raven \\
\hline Dijak št.2 & Ž & 16 let & 55 & 47 & 105 & 95 & Visoka raven \\
\hline Dijak št.3 & Ž & 15 let & 75 & 51 & 126 & 99 & Visoka raven \\
\hline Dijak št.4 & Ž & 16 let & 56 & 40 & 96 & 85 & Visoka raven \\
\hline Dijak št.5 & Ž & 16 let & 45 & 44 & 89 & 75 & Srednja raven \\
\hline Dijak št.6 & Ž & 17 let & 36 & 39 & 75 & 45 & Srednja raven \\
\hline Dijak št.7 & Ž & 16 let & 26 & 17 & 43 & 5 & Nizka raven \\
\hline Dijak št.8 & Ž & 18 let & 58 & 47 & 105 & 95 & Visoka raven \\
\hline
\end{tabular}

Tabela 1: Rezultati prvega testiranja socialne anksioznosti pri mladostnikih

Opombe: Ž - udeleženci ženskega spola, ZSNV - podlestvica zaskrbljenost in strah pred negativnim socialnim vrednotenjem, TZSS - podlestvica tesnobnost in zadržanost $v$ socialnem stiku, LSAA - lestvica socialne anksioznosti za mladostnike, RSA - raven socialne anksioznosti

Pri raziskavi je sicer sodelovalo 10 dijakov in dijakinj, vendar sta dva dijaka projekt zapustila predčasno, zato rezultatov njunih anket $v$ analizo rezultatov nismo uvrstili. Povprečna starost anketirancev je bila 16,13 let. Iz izbranih podatkov je razvidno, da ima natanko polovica dijakinj visoko stopnjo socialne anksioznosti. Povprečna vrednost zaskrbljenosti in strahu pred negativnim vrednotenjem (ZSNV) znaša 48, 63. Povprečna vrednost indeksa tesnobnost in zadržanost v socialnem stiku (TZSS) znaša 40,38. Iz tega lahko sklepamo, da so anketirana dekleta bolj zaskrbljena zaradi možnosti negativnega vrednotenja kot zadržane v socialnem stiku. Povprečna vrednost indeksa lestvica socialne anksioznosti za mladostnike (LSAA) 
predstavlja 89,38, kar nam pove, da imajo anketirane dijakinje v povprečju visoko stopnjo socialne anksioznosti.

\begin{tabular}{|c|c|c|c|c|c|c|c|}
\hline Dijak/dijakinja & Spol & Starost & ZSNV & TZSS & LSAA & Percentil & RSA \\
\hline Dijak št.1 & Ž & 16 let & 60 & 42 & 102 & $90-95$ & Visoka raven \\
\hline Dijak št.2 & Ž & 16 let & 51 & 45 & 96 & 85 & Visoka raven \\
\hline Dijak št.3 & Ž & 17 let & 35 & 37 & 72 & $35-40$ & Srednja raven \\
\hline Dijak št.4 & Ž & 17 let & 54 & 37 & 91 & 80 & Visoka raven \\
\hline Dijak št.5 & Ž & 17 let & 51 & 24 & 75 & 45 & Srednja raven \\
\hline Dijak št.6 & Ž & 17 let & 57 & 31 & 88 & $70-75$ & Srednja raven \\
\hline Dijak št.7 & Ž & 15 let & 39 & 42 & 81 & 60 & Srednja raven \\
\hline Dijak št.8 & Ž & 16 let & 75 & 45 & 120 & 99 & Visoka raven \\
\hline
\end{tabular}

Tabela 2: Rezultati drugega testiranja socialne anksioznosti pri mladostnikih

Opombe: Ž - udeleženci ženskega spola, ZSNV - podlestvica zaskrbljenost in strah pred negativnim socialnim vrednotenjem, TZSS - podlestvica tesnobnost in zadržanost $v$ socialnem stiku, LSAA - lestvica socialne anksioznosti za mladostnike, RSA

- raven socialne anksioznosti

Pri drugem testiranju je bilo anketiranih osem dijakinj. Povprečna starost anketirancev je bila 16,4 let. Iz zbranih podatkov je razvidno, da ima, tako kot pri prvem testiranju, natanko polovica deklet visoko stopnjo anksioznosti. Pri anketiranih dijakinjah sta povprečna vrednost zaskrbljenosti in strahu pred negativnim vrednotenjem (ZSNV) 52,75, kar je v primerjavi s prvim testiranjem slabše za 4,12 enote, kar predstavlja 7,81 \%. Povprečna vrednost indeksa tesnobnost in zadržanost v socialnem stiku (TZSS) pri anketiranih dekletih znaša 37,88 . V primerjavi s prvim testiranjem se je povprečna vrednost indeksa pri dekletih izboljšala za 2,51 enote, kar predstavlja 6,61 \% izboljšanja stopnje tesnobnosti in zadržanosti v socialnem stiku. Povprečna vrednost indeksa lestvica socialne anksioznosti za mladostnike (LSAA) predstavlja 90,63. Iz tega je razvidno, da se je stopnja socialne anksioznosti pri dijakinjah nekoliko poslabšala, in sicer za 1,25 enote.

\begin{tabular}{|c|c|c|c|c|c|c|c|c|c|}
\hline Dijakinja & Starost & ZSNV-PT & TZSS-PT & LSAA-PT & RSA-PT & ZSNV-DT & TZSS-DT & LSAA-DT & RSA-DT \\
\hline Dijakinja št.1 & 16 let & 56 & 40 & 96 & Visoka raven & 60 & 42 & 102 & Visoka raven \\
\hline Dijakinja št.2 & 16 let & 45 & 44 & 89 & Srednja raven & 51 & 45 & 96 & Visoka raven \\
\hline Dijakinja št.3 & 16 let & 75 & 51 & 126 & Visoka raven & 75 & 45 & 120 & Visoka raven \\
\hline Dijakinja št.4 & 17 let & 36 & 39 & 75 & Srednja raven & 35 & 37 & 72 & Srednja raven \\
\hline
\end{tabular}

Tabela 3: Primerjava rezultatov prvega in drugega testiranja socialne anksioznosti za naključne dijakinje

Opombe: PT - rezultati prvega testiranja, DT - rezultati drugega testiranja, ZSNV - podlestvica zaskrbljenost in strah pred negativnim socialnim vrednotenjem, TZSS - podlestvica tesnobnost in zadržanost v socialnem stiku, LSAA - lestvica socialne anksioznosti za mladostnike, RSA - raven socialne anksioznosti 
Ob koncu analize rezultatov smo naključno izbrali štiri dekleta, ki so sodelovala pri obeh testiranjih, da bi ugotovili, ali so se surovi rezultati pri posameznih indeksih po koncu projekta povečali oz. zmanjšali. Pri dijakinji 1 lahko opazimo, da se je indeks zaskrbljenosti in strahu pred negativnim vrednotenjem (ZSNV) nekoliko povečal, in sicer iz 56 na 60, kar pa glede stopnje zaskrbljenosti ne predstavlja prevelike razlike. Prav tako se je pri tej dijakinji indeks tesnobnosti in zadržanosti v socialnem stiku (TZSS) povečal iz 40 na 42, kar prav tako ne predstavlja velike spremembe. Podobno kot oba indeksa se je povečal tudi indeks lestvica socialne anksioznosti za mladostnike (LSAA), vendar samo za surovo vrednost 6 . Podobno sliko imamo tudi pri dijakinji 2, kjer sta se prav tako povečala oba indeksa, in sicer ZSNV za 6 ter TZSS za 1. Kot pri prvi dijakinji tudi pri drugi vidimo, da se je stopnja socialne anksioznosti nekoliko povečala. Pri dijakinji 3 medtem opazimo, da se njena stopnja zaskrbljenosti zaradi možnosti negativnega vrednotenja ni spremenila, se pa je izboljšala stopnja tesnobnosti in zadržanosti v socialnem stiku, čeprav le za surovo vrednost 6 . Tudi indeks lestvica socialne anksioznosti za mladostnike (LSAA) se je pri dijakinji 3 izboljšal za 6, vendar pa njena raven socialne anksioznosti še vedno ostaja visoka. Pri dijakinji 4 po drugi strani opazimo pozitivno spremembo pri vseh indeksih. V primerjavi s prvim testiranjem se je ZSNV izboljšal le za 1; pri indeksu TZSS se je vrednost izboljšala za 2, pri indeksu LSAA za 3. Nobena od sprememb indeksov ni velika, vendar pa se je naš projekt končeval ravno v času zaključevanja letnika in opravljanja prakse, zato so morda rezultati nekoliko zavajajoči - vendar pa vseeno lahko dobimo okvirno sliko statistične uspešnosti projekta.

\subsubsection{Kvalitativni del raziskovanja}

Udeleženci so bili vključeni v dve vrsti delavnic: učenje inšturmenta (pet udeležencev, od tega štiri dekleta in en fant) in petje (11 udeležencev, od tega 10 deklet in en fant). $V$ sklopu delavnic učenja inštrumenta je bilo izvedenih 10 skupinskih srečanj (po 1,5 ure) in osem individualnih srečanj (po 30 minut). Skupinska srečanja so bila razdeljena na 10 različnih tem, ki so se izvajale v obdobju 10 tednov. V sklopu delavnic petja je bilo izvedenih 10 skupinskih srečanj po 1,5 ure. Srečanja so bila razdeljena na 10 različnih tem, ki so se izvajale v obdobju 10 tednov. Skupni cilj je bil zmanjšanje tesnobe pri sodelujočih z udeležbo in nastopanjem na končni produkciji projekta. Poleg uporabe zgoraj navedenih merskih instrumentov smo $v$ raziskovalne namene uporabili še fenomenološko kvalitativno metodo pisanja dnevnika. Izvajalci so tedensko pisali dnevnik z opažanji, čustvenimi stanji, izjavami udeležencev, vtisi. Na podlagi dnevniških zapisov in ob raziskovanju, kakšen vtis so delavnice pustile na udeležence aktivnosti, smo lahko določili sedem izstopajočih tem, ki so bile skupne vsem udeležencem. Te teme so sram, socialna anksioznost (tesnoba), doživljanje samega sebe, stik s čustvi, uglašenost skupnega petja, občutek pripadnosti in občutek pomirjenosti. 
Tema sramu:

„Tukaj lohk pojem, nimam ovir."

"Težko nastopam, ampak te delavnice me osvobodijo."

"Tko nerodn mi je, čeprv tle je kul... ful me sprosčeno nardita."

"Joj grozno je, ko pomislim, da bom nastopala tam pred vsemi."

"Je dosti lažje, če poveš na glas, da ti je nerodno."

Tema socialne anksioznosti (tesnobe):

"Ne vem, tko ko je ponedelk, vem, da bo cel tedn laži."

"Jaz tud mam panike, pa tesnobne napade in mi te vaje res pomagajo; no, saj imam psihoterapevtko, sam ni to to, tuki je res nekaj, ko to mine."

„Včasih mi ful ni za prit sm, ampak pridem in vidm na konc, da je kul, da sem tko $v$ izzy potem, cel teden."

"A veš, da sm, od kr tle vadmo, še v šoli boljš, tko pridm pred tablo in ne razbija srce, ne tresem se, kul je."

"Včasih mi je herc vn padu, ko sem seminarsko mela al pa kaj mogla povedt, zdej pa je lažji, tko si rečem, ko pravta dihaj dihaj, ramena dol, trebuh je balon in se kr pomirim."

"Ko se osredotočim na dihanje, mi pomaga."

"Zadnjič sem se spomnila tiste vaje, ki smo jo delali, in sem začela delat isto. Je blo kul. Pol sem še sošolki pokazala, kako se to dela."

"Prav strah me je, ko pomislim, da bom tam igrala pred vsemi"

Doživljanje samega sebe:

"Včasih mi je res težko, ker vem, da ne rabim bit pousod najboljša in se tako trudit, ampak si ne morem pomagat."

Stik s čustvi:

"Se bojim, da bom razočarala vse doma, če ne bom nrdila vse."

Uglašenost skupnega petja:

Opažanja enega izmed vodij skupine pevske skupine: Dijaki iz tedna v teden pojejo lažje, kot povedo »nimam več cmoka v grlu, tko sproščen je glas", »kot da se mi je grlo odprlu, kut da nimam več kepe nekje v grlu in trebuhu, je tko fajn, no en prostor je«, „nimam več strahu, ko pojem, $\mathrm{kr}$ je se ne tresejo glasilke in cela jaz in tud potem v skupini nimam treme, kr pojem kuk znam in lohka«. Pri skupnem petju je tako opaziti, da lažje petje ustvarja boljše skupno petje, stik med dijaki in s tem večjo uglašenost skupnega petja. 
Občutek pomirjenosti:

„Prsa so sproščena, od kar tuki vadmo, je drgač, tak sem... fajna no." "Vse imam tuk mirno, kot en oblak skozi telo."

"Ja grlo je čist v izy, pa tek ceu no, tud k grem kam nastopat, je zdej boljš, par vajic nrdim in sem kul."

„Tukaj je uredu, ker vemo kaj bomo delali in ti si z nami. Nam ne rečeš samo, lahko rišete, karkoli hočete, in greš. "

Občutek pripadnosti:

"Tuk mi je zal, ka je zadnč, prav navadla sm se."

"Ne nočm, da je konc, tuk mi je fajn z vami, čutim, da napredujem in sem jaz."

„Tuki se res najdm, tak kul mi je, vse si povemo, pa vadmo, pa karkol rečmo, ni tistga ...uuu, kva si reku."

"To je tako fajn, da lahko pridemo sem in povemo vse, kar nas skrbi."

"Tebi lahko use povemo in nas boš poslušala."

\subsection{Interpretacija kvalitativnih podatkov}

Pri hipotezi 1 , da strukturirano, aktivno ukvarjanje z glasbo omogoča lažje prepoznavanje in regulacijo čustev, lahko na podlagi mnenj in samoocen, ki so jih podale udeleženke, glede na značilnosti vzorca postavimo previdno trditev, da so se mladostniki začeli sebe zavedati bolje in da se je zmožnost regulacije čustev okrepila. Dijakinje so dobile globlji vpogled v lastno doživljanje in se začele zavedati, da so vaje iz delavnic orodje za hitrejšo kontrolo nad stresnimi impulzi, ki jih čutijo. Prav tako rezultati kažejo na možnost, da se v stresnih situacijah dijakinje lažje umirijo, ko uporabljajo izkušnje, pridobljene na delavnicah, in da so znanje prenesle v svoje vsakdanje življenje. Pri hipotezi 2 , da vključenost $v$ aktivno vodene glasbene delavnice zmanjšuje stopnjo socialne anksioznosti pri mladostnikih, smo zaznali, da se je sodeč po samooceni stopnja anksioznosti v stresnih okoliččinah, ki jih doživljajo (kot npr. nastopi v šoli) zmanjšala, prav tako se je zmanjšala splošna stopnja socialne anksioznosti, saj so na delavnicah krepili občutek pripadnosti, večal se je občutek pomirjenosti in lažje so se spopadali s sramom. Pri hipotezi 3 , da aktivno glasbeno izražanje mladostnike spodbuja k medsebojnemu povezovanju, lahko glede na vrednotenje srečanj, ki so ga podale dijakinje kot udeleženke, sklenemo, da se je povečal občutek njihove pripadnosti skupini. Med seboj so se povezovale bolje, obenem se je zmanjšal občutek sramu pri nastopanju/izpostavljenosti v skupini; zaznati je tudi večje zavedanje samega sebe, ko so lahko uglašeno sodelovale $v$ skupini z enotnim ciljem.

\section{Sklep}

Z analizo kvantitativne raziskave prihajamo do zaključkov, da so dekleta v prvem testiranju izkazala visoko stopnjo socialne anksioznosti ter visoko stopnjo strahu 
in zaskrbljenosti zaradi možnega negativnega vrednotenja. Pri drugem testiranju se je ocena socialne anksioznosti poslabšala, medtem ko sta se občutek tesnobnosti in zadržanosti v socialnem stiku izboljšala. Testiranje je potekalo v mladostniško najbolj občutljivem okolju in časovnem obdobju - ravno $v$ času zaključevanja šolskih obveznosti, hkrati pa tudi v dijaškem domu, kjer so mladostniki izpostavljeni stresnim dražljajem, ki so povezani s tesnobo in anksioznostjo zaključevanja šolskih obveznosti. V kvalitativnem delu raziskave ugotavljamo, da anketirane mladostnice samoocenjujejo, da jim aktivno ukvarjanje z glasbo omogoča boljše zavedanje sebe, $s$ tem pa boljšo regulacijo čustvenih stanj. Rezultati analize na sicer manjšem in spolno neuravnoteženem vzorcu prav tako kažejo, da aktivno ukvarjanje z glasbo zmanjšuje stopnjo socialne anksioznosti, s tem zmanjšuje občutek sramu in pripomore $\mathrm{k}$ boljšemu spoprijemanju s stresnimi okoliščinami. Pomembno je izpostaviti, da so rezultati kvalitativnega dela analize pokazali, da se je pri anektiranih mladostnicah okrepil občutek pripadnosti, kar povezujemo z izboljšanjem socialne anksioznosti, čustvene regulacije in spoprijemanja s stresnimi dražljaji, kot so izzivi v šoli, sram ter strah pred izpostavljenostjo. Rezultati tudi kažejo, da je aktivno ukvarjanje z glasbo anketirane mladostnice medsebojno povezovalo, saj se je v teku tedenskih srečanj okrepil občutek pripadnosti ob sodelovanju za skupni cilj.

\section{Omejitve raziskave}

Čas, v katerem je potekal projekt, je bil za dijake posebej občutljiv - v drugem semestru in ob koncu šolskega leta. Menimo, da se te okoliščine odražajo na rezultatih in predvidevamo, da bi v drugem časovnem obdobju dobili statistično relevantnejše rezultate, čeprav se je že pri tej raziskavi pokazal trend zmanjševanja socialne tesnobe. Prav tako bi bil potreben večji numerus, da bi te rezultate lahko posplošili na širšo populacijo mladostnikov. $\vee$ nadaljnjem raziskovanju bomo tako vključili kontrolno skupino, s katero bomo trend zmanjševanja socialne tesnobnosti lahko dokazali ali ovrgli. Glasba je način, kako se mladostnik lahko uči prepoznavati svoja čustvena stanja in obenem krepi svojo zmožnost čustvene regulacije. Še pomembneje pa je, da lahko doseže pravo integracijo, ko $v$ pasivno poslušanje glasbe vključi še lastno aktivnost in trud ter poveže svoje telo z možgani in čustvi. In to je tisto, kar mu pomaga pri soočanju z vsakodnevnimi izzivi tega viharnega obdobja. 


\section{Reference}

Airbib, Michael. 2013. Language, Music, and the Brain; The mysterious Relationship. London: MIT.

Anshel, Anat, in David Kipper. 1988. The influence of group singing on trust and cooperation. Journal of Music Therapy, št. 25, 145-155. https://doi.org/10.1093/jmt/25.3.145

Denac, Jerneja. 2013. Vpliv glasbene industrije na odnos mladostnika do popularne glasbe. Socialna pedagogika 17, št. 1-2:113-127.

Disanayake, Ellen. 2009. An Ethological View of Music and its Relevance of Music Therapy. Nordic Yournal of Music Therapy 10, št. 2: 159-175. https://doi. org/10.1080/08098130109478029

Goetze, Mary. 1985. Factors Affecting Accuracy in Children's Singing. Doctoral disertation. Denver: University of Colorado.

Gold, Christian, Martin Voracek in Tony Wigram. 2004. Effects of music therapy for children and adolescents with psychopathology: A meta-analysis. Journal of Child Psychology and Psychiatry 45, št. 6:1054-1063. https://doi. org/10.1111/j.1469-7610.2004.t01-1-00298.x

Gomezel, Anita, in Alenka Kobolt. 2012. Vpliv družine na mladostnikovo identiteto. Socialna pedagogika 16, št. 4:323-354.

Gostečnik, Christian. 2016. So res vsega krivi starši? Ljubljana: Brat Frančišek.

Koelsch, Stefan. 2009. Neuroscientific perspective on music therapy. Annals of the New York Academy of Science, 1169:374-384. V: Landis-Shack, Nora, Adrienne J. Heinz in Marcel O. Bonn-Miller 2017. https://doi. org/10.1111/j.1749-6632.2009.04592.x

Kompan Erzar, Katarina. 2003. Skrita moč družine. Ljubljana: Brat Frančišek.

- - -. 2006. Ljubezen umije spomin. Ljubljana: Brat Frančišek.

- - -. 2015. Pomen umetnosti v razvoju otroka. Dialogi 51, št. 7/8:21-31.

Kuhar, Metka. 2002. O telesni samopodobi mladih. Socialna pedagogika 6, št. 3:255-277.

Landis-Shack, Nora, Adrienne J. Heinz in Marcel O. Bonn-Miller. 2017. Music Therapy for Posttraumatic Stress in Adults: A Theoretical Review. Psychomusicology 27:334-342. https://doi. org/10.1037/pmu0000192

Lešnik, Ivan. 2015. Glasbena aktivnost in uspešnost učencev $v$ osnovni šoli in zunaj nje. $\mathrm{V}$ : Dejan Hozjan, ur. Aktivnosti učencev v učnem procesu 433-452. Koper: Univerzitetna založba Annales. Https://repozitorij.upr.si/IzpisGradiva. php?id=6706 (pridobljeno 1.1.2019).
Malloch, Stephen, in Colwyn Trevarthen. 2010. CommunicativeMusicality: Exploring the basis of human companionship. New York, Oxford: University Press.

Marjanovič Umek, Ljubica, in, Maja Zupančič. 2011. Razvojna psihologija: izbrane teme. Ljubljana: Znanstvena založba Filozofske fakulteta.

McDermott, Josh, in Marc D. Houser. 2006. Thoughts on an Empirical Approach to the Evolutionary Origins of Music.Music Perception. An Interdisciplinary Journal 24, št. 1:111-116. https://doi.org/10.1525/mp.2006.24.1.111

McRae, Kateri, Brent Hughes, Sita Chopra, John D. E. Gabrieli, James J. Gross in Kevin N. Ochsner. 2013. A systematic review on the neural effects of music on emotion regulation: implications for music therapy practice. Front. Psychol 50, št. 3:198-242. https://doi. org/10.1093/jmt/50.3.198

Montello, Louise, in Edgar Coons. 1998. Effects of Active Versus Passive Group Music Therapy on Preadolescents with Emotional, Learning and Behavioral Disordes. Journal of Music Therapy 35 , št 1:49-67. https://doi.org/10.1093/jmt/35.1.49

Mrazova, Marcela, in Peter Celec. 2010. A Systemic review of Randomized Controlled Trials Using Music Therapy for Children. Journal of alternative and complementary medicine 16 , št. 10:1089-1095. https://doi.org/10.1089/ acm. 2009.0430

Miller, Odell H. 2011. Value of music therapy for people with personality disorders. Mental Health Practice 14, št. 10:34-35.

Pate, Tanja. 2016. Sistemska in duhovna perspektiva zdravja in bolezni. Bogoslovni vestnik 76, št. 2:433-439.

Paulander, Ann-Sophie. 2011. Meningen med att gå i musikterapi: En fenomenologisk studie om deltagares upplevelser [The meaning of going in music therapy]. A phenomenological study on the participants' experiences]. Stockholm: KMH Förlaget

Perko, Uroš, in Sonja Čotar Konrad. 2018. Čustvena izraznost družine, struktura družine in volja do bivanjskega smisla oseb iz nealkoholičniih in alkoholičnihi družin. Bogoslovni vestnik 78, št. 1:251-264.

Pepelnak Arnerič, Marija. 1997. Glasbena terapija pri otrocih in mladostnikih z motnjami vedenja in osebnosti. Psihološka obzorja 3, št. 6:97104. Http://www.dlib.si/details/ URN:NBN:SI:DOC-C3TWYR3K (pridobljeno 1.1.2019).

Poljšak Škraban, Olga. 2002. Mladostnik/ca v družini in medsebojno doživljanje družinskih članov. Socialna pedagogika 6, št. 4:369-394. 
Puklek Levpušček, Melita. 2003. Psihosocialne značilnosti mladostnikov z različnim profilom osamosvajanja v odnosu do staršev. Psihološka obzorja 12, št. 4:71-89.

- - - 2006. Socialna anksioznost v otroštvu in mladostništvu: razvojni, šolski in klinični vidik. Ljubljana: Znanstvenoraziskovalni inštitut Filozofske fakultete.

Rorke, Adam M. 1996. Music and the wounded of World War II. Journal of Music Therapy 33, št. 3:189-207. https://doi.org/10.1093/ jmt/33.3.189

Siegel, Daniel. 2014. Vihar v glavi: moč najstniških možganov. Domžale: Terapevtski center pogled.

Simonič, Barbara. 2015. Ranljivost sodobnih družin in spodbuda k materinski rahločutnosti $v$ pastoralni skrbi za družine. Bogoslovni vestnik 75, 3:487-494.

Standley, Jayne. 1996. A meta-analysis ion the effects of music as a reinforcer for education/ therapy objectives. Journal of Research in Mucis Education 44, št. 2:105-133.
Stein, Alexander. 1999. Well-Tempered bagatelles: a meditation on listening in psychoanalysis and music. American Imago 56, št. 4:389-416. https://doi.org/10.1353/aim.1999.0020

Tervo, Jukko. 2005. Music Therapy with Adolescents. Voices: A World Forum for Music Therapy 5, št. 1. Https://voices.no/index.php/voices/ article/view/1727 (pridobljeno 1.1.2019). https://doi.org/10.15845/voices.v5i1.216

Tyller, Kimbel, in Jake Protivnak. 2010. For those about to rock (with your high school students), we salute you: School counselors using music interventions. Journal of Creativity in Mental Health 5, št. 1:25-38. https://doi. org/10.1080/15401381003626857

Žvar, Dragica. 2008. Glasba: Učni načrt. Ljubljana: Ministrstvo za šolstvo in šport, Zavod RS za šolstvo. Http://www.dlib.si (pridobljeno 26.5.2018). 